\title{
The Dynamics of Incidence of Chronic Hepatitis B and C in the Population of Almaty city for 2001-2014
}

\author{
Maria N. Omarova, $\mathrm{PhD}, \mathrm{ScD}$; Lyazat Zh. Orakbay, $\mathrm{PhD}, \mathrm{ScD}^{*}$; \\ Idelbay Kh. Shuratov, PhD, ScD; Aizhan B. Dzhumagalieva PhD; Almas Umbetpaev PhD \\ Scientific Centre of Hygiene and Epidemiology named after Hamza Zhumatov \\ Almaty, Kazakhstan
}

\begin{abstract}
The results of a retrospective epidemiological analysis revealed a sharp decline in the incidence of acute hepatitis B among the entire population of Almaty and the absence of acute hepatitis $\mathrm{B}$, acute hepatitis $\mathrm{C}$ and chronic hepatitis $\mathrm{C}$ among children under 14 years of age. We found an increased incidence of chronic hepatitis B and chronic hepatitis $\mathrm{C}$ among the population of Almaty. Assessment of the hepatitis $\mathrm{C}$ incidence by the cumulative indices more objectively reflects the epidemiological situation for this disease. Int J Biomed. 2016;6(3):222-224.).
\end{abstract}

Key Words: hepatitis B virus • hepatitis C virus • morbidity • cumulative indices.

\section{Introduction}

Hepatitis B virus (HBV) and hepatitis C virus (HCV) remain an urgent health problem in Kazakhstan. An encouraging trend is that the incidence of HBV in Almaty city decreased 9.3 times and has not registered among children under 14 years since 1998, attributable to effective vaccination programs; the prevalence of $\mathrm{HBV}$ carriers also dropped to $2.3 \%-2.6 \%{ }^{[1,2]}$ At the same time, it has been shown that $80 \%$ of HBsAg carriers are people between the ages of 20 and 40 years. ${ }^{[2]}$

Official registration of HCV infections in Kazakhstan and Almaty city started in 1998. In the beginning, only acute hepatitis $\mathrm{C}$ (AHC) was registered; new cases of chronic hepatitis $\mathrm{C}$ (CHC) began to register in 2008. The first observations have shown that the AHC incidence is characterized by low levels(0.4-2.1 in the general population and up to 0.75 in children). ${ }^{[2-4]}$ However, the $\mathrm{CHC}$ incidence was characterized by higher prevalence and tended to increase, largely covering adults as chronic hepatitis $\mathrm{B}(\mathrm{CHB}) .^{[2-4]}$ These features of the incidence of $\mathrm{CHB}$ and $\mathrm{CHC}$ require improving the disease surveillance.

"Corresponding author: Lyazat Orakbay, PhD, ScD. Scientific Centre of Hygiene and Epidemiology named after Hamza Zhumatov. Almaty, Kazakhstan.E-mail: ncgigieny@mail.ru

\section{Materials and Methods}

For the retrospective epidemiological analysis, we used the data of the official registration of the Department of Sanitary and Epidemiological Surveillance of Almaty for HBV and HCV in the intensive indicators from 2001 to 2014. The behavior of the epidemic process was assessed by the annual dynamics of the cumulative incidence of hepatitis B and C. ${ }^{[5]}$

\section{Results and Discussion}

Table 1 shows the average incidence rate for acute hepatitis $\mathrm{B}(\mathrm{AHB})$ in the general population and in children under 14 years of age at 4-5-year intervals for 2001-2014. As can be seen, the AHB morbidity dynamics among the general population tend to decrease.

Table 1.

Dynamics of AHB incidence in Almaty for 2001-2014

\begin{tabular}{|c|c|c|c|c|c|}
\hline \multirow[t]{2}{*}{ Nosology } & \multirow{2}{*}{$\begin{array}{l}\text { population } \\
\text { category }\end{array}$} & \multicolumn{3}{|c|}{$\begin{array}{l}\text { The average annual incidence } \\
\text { rate }\left(\%{ }_{0000}\right) \text { for }\end{array}$} & \multirow{2}{*}{$\begin{array}{l}\text { Multiplicity } \\
\text { reduction }\end{array}$} \\
\hline & & $2001-2005$ & $2006-2010$ & $2011-2014$ & \\
\hline \multirow[b]{2}{*}{ AHB } & $\begin{array}{l}\text { Gene } \\
\text { popu }\end{array}$ & 20.0 & 5.5 & 1.5 & 13.3 \\
\hline & $\begin{array}{l}\text { children under } \\
14 \text { years of age }\end{array}$ & 1.01 & 0.0 & 0.0 & $\begin{array}{c}\text { Absence of } \\
\text { AHB }\end{array}$ \\
\hline
\end{tabular}


The average rate for 2001-2005 was 20.0 per 100,000 and dropped to 1.5 in 2011-2014. Multiplicity reduction amounted to 13.3 times. More striking dynamics were observed for AHB among children under 14 years of age. The AHB incidence was recorded only during 2001-2004. The average rate was 1.01 per 100,000 children. Since 2005 in Almaty, AHB has not been registered among children. These data conclusively demonstrate the epidemiological effectiveness of $\mathrm{HBV}$ vaccination in children.

The results of a similar analysis for AHC incidence are shown in Table 2. During the analyzed period, the isolated cases of AHC were recorded annually: figures ranged from 0.6 to $1.14 \%{ }_{0000}$. AHC cases were not registered among children. Generally, AHC is uncommon in childhood, ${ }^{[6,7]}$ and most chronically infected children are asymptomatic with normal growth and development.

Table 2.

Dynamics of AHC incidence in Almaty for 2001-2014

\begin{tabular}{|c|c|c|c|c|c|}
\hline \multirow[t]{2}{*}{ Nosology } & \multirow{2}{*}{$\begin{array}{l}\text { population } \\
\text { category }\end{array}$} & \multicolumn{3}{|c|}{$\begin{array}{c}\text { The average annual incidence } \\
\text { rate }\left(\%{ }_{0000}\right) \text { for }\end{array}$} & \multirow{2}{*}{$\begin{array}{l}\text { Multiplicity } \\
\text { reduction }\end{array}$} \\
\hline & & $2001-2005$ & $2006-2010$ & 2011-2014 & \\
\hline \multirow[b]{2}{*}{$\mathrm{AHC}$} & $\begin{array}{l}\text { General } \\
\text { population }\end{array}$ & 1.14 & 0.24 & 0.6 & 1.9 \\
\hline & $\begin{array}{l}\text { children under } \\
14 \text { years of age }\end{array}$ & 0.00 & 0.00 & 0.00 & - \\
\hline
\end{tabular}

The standard case definition for AHCV was adapted from World Health Organization recommendations. ${ }^{[8]}$ It is necessary to diagnose AHCV based on epidemiological and clinicobiochemical findings, such as the presence of newly identified markers of $\mathrm{HCV}$ - antibodies to HCV (anti-HCV) and HCV RNA. Unlike with AHB - in which the IgM antibody to the hepatitis $\mathrm{B}$ core antigen is diagnostic of acute infection and precedes the appearance of IgG-with HCV infection the IgM antibody responses are variably detected in both acute and chronic phases ${ }^{[9]}$ Anti-HCV IgM cannot therefore serve as a diagnostic marker of acute HCV infection. In this context, the continuing practice of determining IgM for the diagnosis of acute hepatitis $\mathrm{C}$ in Kazakhstan is incorrect.

In recent years, the incidence of $\mathrm{CHB}$ and $\mathrm{CHC}$ has increased. ${ }^{[1,12]}$ Table 3 illustrates the dynamics of incidence of CHB and CHC in Almaty for 2003-2014 years.

Table 3.

Dynamics of incidence of CHB and CHC in Almaty for 2003-2014

\begin{tabular}{|c|c|c|c|c|}
\hline \multirow{2}{*}{ Nosology } & \multicolumn{3}{|c|}{ The average annual incidence rate } & \\
\cline { 2 - 5 } & $2003-2006$ & $2007-2010$ & $2011-2014$ & Multiplicity increase \\
\hline CHB & 6.1 & 5.1 & 11.6 & 1.9 \\
\hline CHC & 4.7 & 4.1 & 14.8 & 3.1 \\
\hline
\end{tabular}

In particular, from the time of registration in 2003 the incidence of $\mathrm{CHB}$ and $\mathrm{CHC}$ has tended to increase, and has increased 1.9 and 1.3 times, respectively. Taking into account the incorrectness of the separate account of AHC cases and treating them as the manifestation of $\mathrm{CHC}$ cases, we calculated the cumulative incidence rates of $\mathrm{HCV}$, the average indices of which were compared with the average annual rates of CHB (Table 4).

Table 4.

Dynamics of the cumulative incidence rates of $\mathrm{CHC}$ and $\mathrm{CHB}$ in Almaty for 2003-2014

\begin{tabular}{|c|c|c|c|c|}
\hline \multirow{2}{*}{ Nosology } & \multicolumn{3}{|c|}{ The average $\begin{array}{c}\text { annual incidence rate } \\
\left(\%{ }_{0000}\right) \text { for }\end{array}$} & \multirow{2}{*}{$\begin{array}{c}\text { Multiplicity } \\
\text { increase }\end{array}$} \\
\cline { 2 - 4 } & $2003-2006$ & $2007-2010$ & $2011-2014$ & \\
\hline CHC & 5.5 & 4.3 & 15.0 & 2.7 \\
\hline CHB & 6.1 & 5.1 & 11.6 & 1.9 \\
\hline
\end{tabular}

CHC incidence, according to cumulative indices, was slightly higher than the CHB incidence, especially in 20112014. These results indicate an epidemiological potential of $\mathrm{CHC}$ and require attention to the public health problem. Analysis of the distribution of patients with $\mathrm{CHC}$ and $\mathrm{CHC}$ by age groups showed that $80 \%$ to $90 \%$ of patients are between 20 and 49 years of age.

Thus, the results of a retrospective epidemiological analysis revealed a sharp decline in the AHB incidence among the entire population of Almaty and the absence of AHC and $\mathrm{AHC}$ among children under 14 years of age. Registered isolated cases of AHC, apparently, are a manifestation of CHC cases.

We found an increased incidence of $\mathrm{CHB}$ and $\mathrm{CHC}$ among the population of Almaty. Assessment of the hepatitis $\mathrm{C}$ incidence by the cumulative indices more objectively reflects the epidemiological situation for this disease. These circumstances have to be understood by epidemiologists for effective and quality monitoring of hepatitis C. CHB and $\mathrm{CHC}$, being a risk factor for hepatocellular carcinoma and liver cirrhosis, should be a focus of the healthcare system in Kazakhstan.

\section{Competing interests}

The authors declare that they have no competing interests.

\section{References}

1. Shuratov IH, Dzhumagalieva AB, Ospanova EN et al. The impact of HBV vaccination on the hepatitis B incidence. Proceedings of the International Conference "Actual problems of parenteral infections." Bishkek, 2005:118-20.

2. Shuratov IH, Omarova MN, Dzhumagalieva AB, et al. Improving the quality and efficiency of the etiological and epidemiological control (supervision) of HCV - infection (Guidelines). Almaty; 2011, 20 pp.

3. Utegenova ES, Shuratov IH, Han OE. Incidence of hepatitis $\mathrm{C}$ in population of Kazakhstan. Hygiene Epidemiology and Immunology. 2008;:3:66-70.

4. Shuratov IH., Omarova MN., Hhan OE. и др. The hepatitis $\mathrm{C}$ virus and hepatitis $\mathrm{C}$ (handbook). Almaty; 2009, 32pp. 
5. Centers for Disease Control and Prevention (U.S.), Career Development Division. Principles of epidemiology in public health practice: an introduction to applied epidemiology and biostatistics. 3rd edition. U.S. Dept. of Health and Human Services, Centers for Disease Control and Prevention (CDC), Office of Workforce and Career Development, Atlanta, GA; 2006. 6. Kelly D. Viral hepatitis B and C in children. J R Soc Med. 20061; 99(7): 353-7.

7. Orland JR, Wright TL, Cooper S. Acute hepatitis C. Hepatology. 2001; 33(2):321-7.

8. WHO. WHO-Recommended Standards for Surveillance of Selected Vaccine-Preventable Diseases. Geneva: WHO; 2003. [WHO/V\&B/03.01].
9. Quinti I, Hassan NF, El Salman D, Shalaby H, El Zimatty D, Monier MK, Arthur RR. Hepatitis C virus-specific B cell activation: $\operatorname{IgG}$ and $\operatorname{IgM}$ detection in acute and chronic hepatitis C. J Hepatol. 1995; 23:640-7.

10. Pawlotsky JM. Molecular diagnosis of viral hepatitis. Gastroenterology. 2002;122(6):1554-68.

11. Rein DB, Wittenborn JS, Weinbaum CM, Sabin M, Smith BD, Lesesne SB. Forecasting the morbidity and mortality associated with prevalent cases of pre-cirrhotic chronic hepatitis C in the United States. Dig Liver Dis. 2011;43:66-72 12. Mukomolov S, Trifonova G, Levakova I, Bolsun D, Krivanogova E1. Hepatitis C in the Russian Federation: challenges and future directions. Hepat Med. 2016;8:51-60. 